\title{
Hiperparasitism on mycotoxigenic fungus Aspergillusochraceus G. Wilh. By Cladosporiumcladosporioides (Fresen) de Vries Caroline Lima Angélico ${ }^{1}$, Sára Maria Chalfoun ${ }^{2}$, Mário Lúcio Vilela de Resende ${ }^{3}$ \\ ${ }^{1}$ Fellowship, PhD - INCT do Café, Universidade Federal de Lavras, Brazil \\ ${ }^{2}$ Researcher, PhD - EPAMIG Sul, Brazil \\ ${ }^{3}$ Professor, PhD - Universidade Federal de Lavras, Researcherof INCT do Café, Universidade Federal de Lavras, Brazil
}

\begin{abstract}
Biocontrol agents (BCAs) for the control of fungal diseases and pests has been the focus in the development of, thus, the agrochemical industry has refocused priorities on integrated control to include the use of BCAs in research and programmes for disease and pest control. The mechanism of action has often included direct antagonism between the BCA and fungal pathogen, competitive exclusion of the pathogen by niche occupation, production of secondary metabolites, hyperparasitism, and the production of volatile organic compounds(VOCs). It is considered as a characteristic of antagonist, to present more than one mechanism, because in this way, their chances of success are increased. The present study, objectived to evaluate, in vitro, competition between the fungus considered a bioprotective agent of the coffee quality Cladosporiumcladosporioides (Fresen) de Vries and the potentially toxigenic fungus Aspergillus ochraceus G. Wilh. Competition between isolates of $C$. cladosporioides and A. ochraceus was evaluated in vitro conditions by adding conidia aliquotas in Petri dishes containing PDA (potato, dextrose, ágar) culture medium.The antagonist relationship between isolates was observed in Olympus SZX7TR-ILA trinocular stereoscopic microscope coupled to a camera and in scanning electron microscopy ZEISS ${ }^{\circledR}$. The fungus C. cladosporioides (Fresen) de Vries, showed its antagonism on potencialmycotoxigenic fungus A. ochraceus by of antibiosis and hyperparasitism mechanisms.
\end{abstract}

Keywords-Biocontrol, sustainability, food safe.

\section{INTRODUCTION}

In the coffee crop, favorable conditions for the development of fungi can contribute to the depreciation of the beverage, due to the taste produced by the fermentations, besides compromising the safety by the production of mycotoxins, being the main mycotoxigenicfungal genera Aspergillus, Penicillium and Fusarium, contaminants coffee plantations[1].OchratoxinA (OTA) is a naturally occurring foodborne mycotoxin found in a wide variety of agricultural commodities worldwide, ranging from cereal grains to dried fruits to wine and coffee. It is produced by several different fungi including Aspergillus ochraceus, A. carbonarius, A. niger and Penicilliumverrucosum[2].

Biocontrol agents (BCAs) for the control of fungal diseases and pests has been the focus in the development of, thus, the agrochemical industry has refocused priorities on integrated control to include the use of BCAs in research and programmes for disease and pest control. The mechanism of action has often included direct antagonism between the BCA and fungal pathogen, competitive exclusion of the pathogen by niche occupation, production of secondary metabolites, hyperparasitism, and the production of volatile organic compounds (VOCs)[3]. It is considered as a characteristic of antagonist, to present more than one mechanism, because in this way, their chances of success are increased[4].

Based on the antagonistic interactions and in the several studies on coffee quality, the fungus Cladosporiumcladosporioides (Fresen) de Vries can be considered as antagonistic agent against harmful fungi to quality beverage[5].Studies show that the microorganism acts through the mechanisms of competition antibiosis and parasitism, due to the great capacity for natural adaptation, as well as the rapid capacity to colonize the substrate[6]. In the antibiosis process, the production of cladosporol by the fungus Cladosporium sp. is responsible for the inhibition of the development of insects and other fungi species, and its action as a parasite has been shown to promote hyperparasitism in some fungi species[7].

The present study, objective to evaluate, in vitro, competition between the funguses considered a bioprotective agent of the coffee quality Cladosporiumcladosporioides (Fresen) de Vriesandthe potentially toxigenic fungus Aspergillus ochraceus G. Wilh.

\section{MATERIAL AND METHODS}

The tests were carried out at the Laboratory of Phytopathology and Microbiology of EPAMIG Sul in Lavras-MG and in the Laboratory of Electron Microscopy and Ultra-structural Analysis (LME / UFLA), according to the methodology proposed 
by[8]. The isolates of the fungi Cladosporiumcladosporioides (Fresen) de Vries and Aspergillus ochraceus G. Wilhtested were already identified and deposited in the collection of microorganisms culture of the Department of Food Science / UFLA.

In each Petri dish containing a purified colony of each isolate, $40 \mathrm{~mL}$ of distilled and sterilized water was added. Then the mycelium was scraped to obtain a suspension which was subsequently filtered with the aid of a sterile gauze to obtain only the spores. After filtration, an $30 \mu \mathrm{L}$ aliquot of spore solution was transferred by means of an automatic pipette to Petri dishes of $6 \mathrm{~cm}$ in diameter containing PDA (potato, dextrose, ágar) culture medium, the solution being spread by Drigalsky's handle.

After inoculation, the plates were maintained in BOD at $25{ }^{\circ} \mathrm{C}$ with a 12 -hour photoperiod, and the spore germination behavior was observed by an Olympus SZX7TR-ILA trinocular stereoscopic microscope coupled to a camera and by scanning electron microscopy Zeiss ${ }^{\circledR}$ with competition observed at 3, 10 and 20 days. The fungus $C$. cladosporioides (Fresen) de Vries, showed its antagonism on potencialmycotoxigenic fungus A. ochraceusby of antibiosis and hyperparasitism mechanisms.

\section{RESULTS AND DISCUSSION}

At 20 days, the deformation of some Aspergillus ochraceus G. Wilh spores was observed under the scanning optical microscope in addition to the total inhibition of germination due to the presence of Cladosporiumcladosporioides (Fresen) de Vries, in contrast to the treatment inoculated only with fungus A. ochraceus $\mathrm{G}$. Wilh.

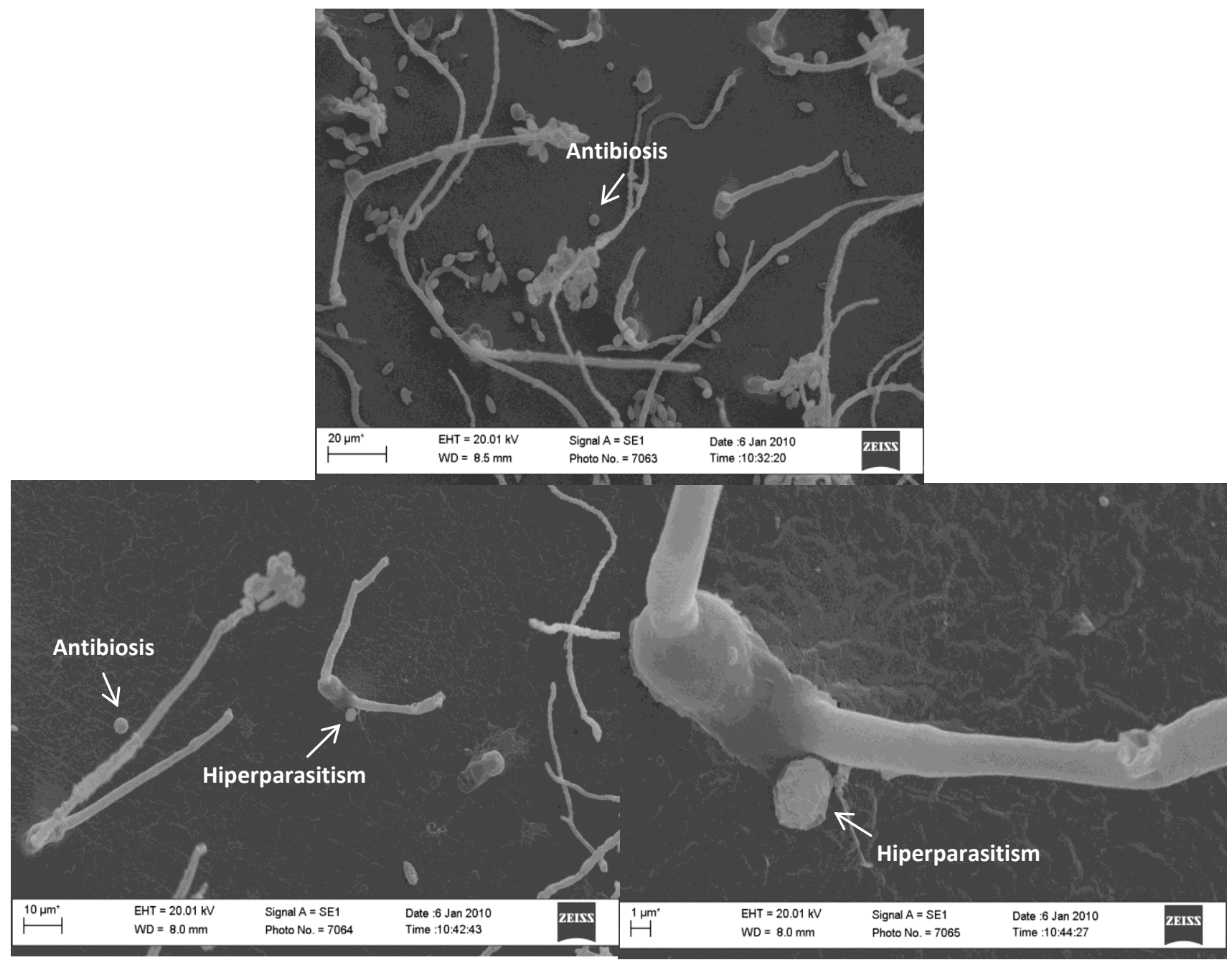

FIGURE.1: In vitrohyperparasitism between $C$. cladosporioides (Fresen) de Vries and $A$. ochraceusG. Wilh with 20 days of competition. (A) Structure of $C$. cladosporioides (Fresen) de Vries formed and conidia of $A$. ochraceus G. Wilh (B) Hyperparasitism of C. cladosporioides (Fresen) de Vries on conidia of $A$. ochraceus G. Wilh. (C) Detail of the degradation of the conidium of A. ochraceus $G$. Wilh. 
The Fig. 1 demonstrates the hyperparasitism exerted by Cladosporiumcladosporioides (Fresen) de Vries on Aspergillus ochraceus $\mathrm{G}$. Wilh. with 20 days of in vitrocompetition.

In the Fig. 1A, it can be observed that the structure of the C. cladosporioides(Fresen) de Vries is fully formed, and whereas the fungus A. ochraceus G. Wilhalthough presented its circular shape and smooth texture but doesn't germinated by the antibiosis effect of the C. cladosporioides.

Figure 1B shows hiperparasitism effect by differences in size and texture between the conidia of A. ochraceus G. Wilh, which was in contact with the hypha of $C$. cladosporioides (Fresen) de Vries and conidia without contact with the hypha.

In the detail of figure $1 \mathrm{C}$, it is possible to better understand that the hypha of $C$. cladosporioides(Fresen) de Vries has a point of contact with the conidium of Aspergillus ochraceus G. Wilh, probably involving the production of extracellular lytic enzymes responsible for cellular membrane degradation and consequent disruption of the microbial cell. The pathogen suppression of several plants worldwide is due to the occurrence of naturally occurring hyperparasites[9], demonstrating appressory formation and penetration into the host by means of mechanical force[10] or enzymatic breakdown[11].

\section{CONCLUSION}

The fungus $C$. cladosporioides (Fresen) de Vries, showed its antagonism on potencialmycotoxigenic fungus A. ochraceus by of antibiosis and hyperparasitism mechanisms

\section{ACKNOWLEDGEMENTS}

Authors want to thank: INCT of Coffee - National Institute of Coffee Science and Technology; EPAMIG - Agricultural Research Company of Minas Gerais; FAPEMIG - Foundation for Research Support of Minas Gerais; CNPq - National Council for Scientific and Technological Development.

INCT do Café - Instituto Nacional de Ciência e Tecnologia do Café; EPAMIG - Empresa de Pesquisa Agropecuária de Minas Gerais; FAPEMIG - Fundação de Amparo à Pesquisa de Minas Gerais; CNPq - Conselho Nacional de Desenvolvimento Científico e Tecnológico.

\section{REFERENCES}

[1] Chalfoun, S.M. and Parizzi, F.C.Toxigenic fungi and mycotoxins in coffee. p.217-231.In: Handbook of coffee post-harvest technology. FlávioMeiraBorém Ed.2014.282 p.

[2] Bui-Klimke, T.R. and Wu, F. Ochratoxin A and human health risk: A review of the evidence. Crit Rev Food SciNutr.v.55, n.13, p. 1860-1869, 2015.

[3] Medina, A.; Mohale, S.; Iskandar, N.; Samsudin, P.; Rodriguez, A.; Rodriguez, S.A. and Magan, N. Biocontrol of mycotoxins: dynamics and mechanisms of action. CurrentOpinion in Food Science, v. 17, p. 41-48, 2017.

[4] Remuska, A. C. and Pria, M. D. Efeito de Bacillusthuringiensise Trichodermasp.no crescimento de fungos fitopatogênicos. ScientiaAgricola,Piracicaba, v. 13, n. 3, p. 31-36, 2007.

[5] Chalfoun, S. M. Biological control and bioactive microbial metabolites: a coffeequality perspective.Ciência e Agrotecnologia, Lavras, v. 34, n. 5, p. 1071-1085, set./out. 2010.

[6] Pereira, R. T. G.; Pfenning, L. H.and Castro, H. A. Caracterização e dinâmica de colonização de Cladosporiumcladosporioides (Fresen.) de Vries em frutos do cafeeiro (Coffeaarabica L.).Ciência e Agrotecnologia,Lavras, v. 29, n. 6, p. 1112-1116, nov./dez. 2005.

[7] Bermejo, L. P. S.; Botelho, D.M.S. and Souza, S. M. C. Antifungal activity of extracts of Cladosporiumcladosporioides (Fres) de Vries. Journal of Pure and Applied Microbiology, v. 8, p. 2791-2799, 2014.

[8] Alves, E. Introdução à microscopia eletrônica de varredura. Lavras: UFLA/FAEPE, 2004. 43 p.

[9] Nasini, G.; Arnone, A.; Assante, G.; Bava, A.; Moricca S.andRagazzi, A. Secondary mouldmetabolites of Cladosporiumtenuissimum, a hyperparasiterust fungi. Phytochemistry, Saint Paul, v. 65, p. 2107-2111, 2004.

[10] Moricca, S.; Ragazzi, A.; Mitchelson,K.R. and Assante, G.Antagonism of the two-needle pine stem rust fungi Cronartiumflaccidum and Peridermiumpini by Cladosporiumtenuissimumin vitro and in planta. Phytopathology, Saint Paul, v. 91, p. 457-468, 2001.

[11] Assante, G. et al. Hystological studies on the mycoparasitism of Cladosporiumtenuissimum and urediniospores of Uromycesappendiculatus. Mycology Research, New York, v. 108, n. 2, p. 170-183, Apr. 2004. 